\title{
The Visible Hand and the Crowd Analyzing Organization Design in Distributed Innovation Systems
}

\author{
Kornberger, Martin
}

Document Version

Accepted author manuscript

Published in:

Strategic Organization

DOI:

$10.1177 / 1476127016648499$

Publication date:

2017

License

Unspecified

Citation for published version (APA):

Kornberger, M. (2017). The Visible Hand and the Crowd: Analyzing Organization Design in Distributed Innovation Systems. Strategic Organization, 15(2), 174-193. https://doi.org/10.1177/1476127016648499

Link to publication in CBS Research Portal

\section{General rights}

Copyright and moral rights for the publications made accessible in the public portal are retained by the authors and/or other copyright owners and it is a condition of accessing publications that users recognise and abide by the legal requirements associated with these rights.

Take down policy

If you believe that this document breaches copyright please contact us (research.lib@cbs.dk) providing details, and we will remove access to the work immediately and investigate your claim. 


\section{The Visible Hand and the Crowd: Analyzing Organization Design in Distributed Innovation Systems}

\section{Martin Kornberger}

Journal article (Post print version)

CITE: The Visible Hand and the Crowd: Analyzing Organization Design in Distributed Innovation Systems. / Kornberger, Martin. In: Strategic Organization, Vol. 15, No. 2, 2017, p. 174-193.

DOl: 10.1177/1476127016648499

Uploaded to Research@CBS: June २०17 


\title{
The Visible Hand and the Crowd:
}

\section{Analyzing Organization Design in Distributed Innovation Systems ${ }^{1}$}

\author{
Professor Martin Kornberger \\ Department of Organization \\ Copenhagen Business School
}

Kilevej 14A

DK-2000 Frederiksberg

Denmark

Email: $\underline{\text { mko.ioa@,cbs.dk }}$

\footnotetext{
${ }^{1}$ I would like to thank José Ossandón, David Stark, Vitaliano Barberio, Stefano Ponte, Christian Frankel, Eric von Hippel, Christof Brandtner, Alfred Kieser and the participants at a Zeppelin University seminar about The Visible Hand and the Crowd in spring 2013 for their comments. I would also like to thank the three reviewers for their constructive comments and the editors of this special issue for their guidance.
} 


\begin{abstract}
The effectiveness and creativity of Linux, Wikipedia and a plethora of other distributed innovation systems has attracted the attention of scholars, practitioners and policy makers. The hallmark of these distributed innovation systems is that value creation transcends the boundaries of hierarchically organized firms. To date, only relatively few studies have focused on the organization design of distributed innovation systems. This conceptual paper addresses this lacuna by asking: How does organization design structure relationships in distributed innovation systems, including interactions between the "visible hand" of the manager and the "crowd" of distributed innovation? The purpose of this paper is to shift the unit of analysis of organization design from the individual firm to networks of actors providing a framework to study how design organizes distributed innovation systems. In order to do so three design mechanisms (interface design; the design of participatory architectures; and the design of evaluative infrastructures) are proposed through which firms and other network actors organize their encounter in "the open" and through which they manage communication, coordination of tasks and control in distributed innovation systems.
\end{abstract}

Keywords: organization theory, organization design, distributed innovation, crowds, search, strategy 
The imperatives of technology and organization, not the images of ideology, are what determine the shape of economic society.

John Kenneth Galbraith, The New Industrial State (1967)

\section{Introduction: The visible hand and the crowd}

Distributed innovation systems have emerged as powerful and creative sources of new ideas, services and technologies. For instance, thousands of amateur contributors make Wikipedia the most comprehensive encyclopedia in the world. The open source codebase Linux provides sophisticated software, used even for what the U.S. government terms mission critical tasks. Since the start of Apple's open App Store, approximately 1.5 million applications have been developed by close to 400,000 publishers and downloaded 75 billion times. In the first week of 2015 alone customers spent nearly half a billion dollars on apps and in-app purchases. ${ }^{2}$ These examples illustrate how distributed actors in innovation networks act effectively as producers and bricoleurs, creative users and (occasionally) abusers of new products, services and experiences. Taking these shifting locus of innovation from firms to networks (Powell et al., 1996) as its point of departure, this paper focuses on one hitherto neglected question: How does organization design, defined as the structuring of communication, coordination and control (Simon, 1969, 1962) enable as well as constrain the activities within distributed innovation networks?

Save for a few exceptions (Baldwin, 2012; Gulati et al., 2012: Fjeldstad et al., 2012; Lakhani et al., 2013; Altman et al., 2015), extant research does not focus sufficiently on organization design and its

\footnotetext{
${ }^{2}$ See http://148apps.biz/app-store-metrics/ and https://www.apple.com/pr/library/2015/01/08App-Store-Rings-in-2015-with-New-Records.html
} 
role in structuring relationships within distributed innovation systems, including those between hierarchical firms, individual entrepreneurs, collectives and other actors. As Baldwin observed in the context of distributed innovation, "the so-called 'modern corporation' has long been the central focus of the field of organization design. [...] But individual organizations are no longer adequate to serve as the primary unit of analysis" (2012: 1). Therein lies the challenge this paper addresses: How to extend theory of organization design beyond firm boundaries and explicate how organization design mechanisms structure systems of distributed innovation?

This paper provides an answer to this question by proposing a novel conceptualization of organization design that explores how communication, coordination and control are achieved in distributed innovation systems. Complementing theories of design for hierarchies and markets (Williamson, 1985, 1991), this paper makes a specific contribution to organization theory through mapping a framework for organization design in distributed innovation systems. In order to do so this paper proposes three concrete design principles that resolve challenges of communication, coordination and control in distributed innovation systems. First, interface design is concerned with the organization of the interaction within distributed innovation systems (mediating function); second, the design of participatory architectures enables users to articulate their ideas and contribute meaningfully to distributed innovation (enabling function); and, third, evaluative infrastructures function as accounting mechanisms to judge the quality and value of production in distributed innovation systems (valuation function). In so doing this paper provides one step towards answering Boudreau and Lakhani’s call that we need to "put as much energy and intelligence into designing systems for organizing work outside company walls as we do for work within them” (2013: 69).

The proposed theoretization of organization design advances our understanding of organizing crowds and innovation in several ways. First, it offers a better understanding of the design mechanisms that structure distributed innovation processes. Akin to Ford's assembly line that 
represented an organizational innovation for manufacturing physical goods (Weber, 2004), the proposed design principles represent an invisible infrastructure that organizes economic activity in distributed innovation systems. Second, this paper contributes to the development of a design-based theory of search in distributed innovation systems (Simon, 1969). Third, it adds to the resource-based literature by explicating how organization design functions as an access mechanism to knowledge, creativity, human ingenuity and other resources that reside outside firm boundaries.

The paper is structured as follows. First, it analyzes research on distributed innovation and situates its argument within this ongoing conversation. Next it discusses the conceptualization of organization design along three main trajectories (interface design, design of architectures of participation and design of evaluative infrastructures). This section draws on and enhances the interdisciplinary discourse of organization theory by grounding the three functions of organization design analytically in software and media studies (concern with interfaces), the distributed innovation literature (concern with architectures) and economic sociology and accounting studies (concern with valuation). Then the paper discusses the implications for organization theory, search and the resource based view. Finally, it reflects on future empirical research opportunities and concludes with a reflection on management practice and the political economy of distributed innovation.

\section{Theoretical context: distributed innovation and the question of organization design}

Next this paper will review extant research on distributed innovation in order to locate the paper's theoretical context, clarify the domain of applicability of the proposed framework as well as indicate where and how it departs from previous studies.

\section{Defining distributed innovation systems}

Several different conceptualizations of the phenomenon of distributed innovation compete for the scholar's attention, including user driven innovation (von Hippel, 2005), commons-based peer 
production (Benkler, 2002), platform innovation (Gawer and Cusumano, 2002; 2008), co-creation (Prahalad and Ramaswamy, 2004), crowdsourcing (Afuah and Tucci, 2012, 2013; Bloodgood, 2013) and other forms of collaboration with outsiders (see table 1).

\begin{tabular}{|c|c|c|c|}
\hline Theory \& domain & Key idea & Analytical focus & Exemplary theorists \\
\hline $\begin{array}{l}\text { Lead user innovation } \\
\text { Domain: innovation }\end{array}$ & $\begin{array}{l}\text { Information asymmetry and } \\
\text { differences in information quality } \\
\text { between lead users and innovation } \\
\text { managers enable the former to } \\
\text { outperform the latter }\end{array}$ & $\begin{array}{l}\text { Economics and dynamics of lead } \\
\text { user innovation in contrast to } \\
\text { traditional R\&D management }\end{array}$ & $\begin{array}{l}\text { Von Hippel, 1976; } \\
\text { 1986; 2005 }\end{array}$ \\
\hline $\begin{array}{l}\text { Value co-creation } \\
\text { Domain: strategy \& } \\
\text { marketing }\end{array}$ & $\begin{array}{l}\text { Value creation as distributed } \\
\text { process that takes place in eco- } \\
\text { system in which consumers, } \\
\text { suppliers, business partners and } \\
\text { others co-produce value }\end{array}$ & $\begin{array}{l}\text { Analyzing value creation } \\
\text { ecosystems and how consumers } \\
\text { are enrolled in distributed } \\
\text { innovation }\end{array}$ & $\begin{array}{l}\text { Normann and } \\
\text { Ramirez, 1993; } \\
\text { Prahalad and } \\
\text { Ramaswamy, 2004; } \\
\text { Vargo and Lusch, } \\
2004\end{array}$ \\
\hline $\begin{array}{l}\text { Platform innovation } \\
\text { Domain: innovation } \\
\& \text { strategy }\end{array}$ & $\begin{array}{l}\text { Platforms as products, services or } \\
\text { technologies that function as } \\
\text { foundations for complementors to } \\
\text { innovate }\end{array}$ & $\begin{array}{l}\text { Focus on dynamic interplay of } \\
\text { collaboration, competition and } \\
\text { strategic choices characterizing the } \\
\text { relationship between } \\
\text { complementors and platform } \\
\text { owners }\end{array}$ & $\begin{array}{l}\text { Gawer and } \\
\text { Cusumano, 2002; } \\
2008\end{array}$ \\
\hline $\begin{array}{l}\text { Commons-based } \\
\text { peer production } \\
\text { Domain: law and } \\
\text { political economy }\end{array}$ & $\begin{array}{l}\text { The social logic of peer } \\
\text { production coordinates distributed } \\
\text { innovation and creates a commons } \\
\text { as shared resource }\end{array}$ & $\begin{array}{l}\text { Peer production as alternative } \\
\text { coordination mechanism to the } \\
\text { visible hand of the manager and } \\
\text { the invisible hand of the market }\end{array}$ & Benkler, 2002; 2006 \\
\hline
\end{tabular}

Table 1: Mapping extant research on distributed innovation

These approaches share the assumption that the "locus of innovation" shifts from hierarchically structured firms to networks of distributed actors (Powell, 1990; Powell et al., 1996), theorizing innovation as a distributed process to which users, rivals and other non-firm members contribute (von Hippel, 1988; Lakhani and Panetta, 2007; Baldwin and von Hippel, 2011; Bogers and West, 2012). These approaches define distributed innovation as "decentralized problem-solving, selfselected participation, self-organizing coordination and collaboration, 'free' revealing of knowledge, and hybrid organizational models that blend community with commercial success" (Lakhani and Panetta, 2007: 98). The constitutive elements include crowdsourcing, contests and tournaments as forms of distributed innovation (see Pisano and Verganti, 2008; Boudreau and Lakhani, 2009; 2013) 
which together define the domain of applicability for the organization design framework of distributed innovation developed in this paper. ${ }^{3}$

Importantly, the role of information and communication technology in distributed innovation systems has to be acknowledged (see Zammuto et al., 2007; Lakhani et al., 2013; Altman et al., 2015). Knowledge and informational goods can be digitized and travel through the internet via a rapidly spreading infrastructure of socio-cognitive processing devices, including PCs, laptops, smartphones, tablets and so on (Lakhani et al., 2013). The shared information is transmitted, stored and manipulated at ever declining costs and at ever increasing speeds. Past technology advances such as filing systems, phones, fax machines, etc. have contributed to an increase in the internal efficiency of organizations (Yates, 1989). This has led to a decrease in management costs. The internet, on the other hand, is a technology that networks society and, hence, reduces communication, information and search costs (Langlois, 2003; Langlois and Garzarelli, 2005; Altman et al., 2015). Questions concerning how to find the right supplier to deliver crucial input just in time become, thanks to technology, easier to answer. Firms such as Procter \& Gamble search globally for talent to help solve the challenges it faces or to identify new opportunities; similarly, Innocentive is an open platform for crowdsourcing solutions for problems experienced in the pharmaceutical industry (Huston and Sakkab, 2006; see also Pisano and Verganti, 2008; Boudreau and Lakhani, 2013). These examples

\footnotetext{
${ }^{3}$ The definition excludes open innovation (Chesbrough, 2003) because it is predominantly concerned with commercialization of distributed innovation from a firm perspective (Lichtenthaler, 2011) and revenue-generating practices form a firm perspective (Bogers and West, 2012). Open innovation is defined as "the use of purposive inflows and outflows of knowledge to accelerate internal innovation, and expand the markets for external use of innovation, respectively" (Chesbrough, 2006: 1). Consequently, open innovation studies focus on value capturing mechanisms that enable "the organization to sustain its position in the industry value chain over time" (Chesbrough, 2006: 2; see also Chesbrough, 2003; Fosfuri et al., 2008). In contrast, distributed innovation systems shift the analytical focus from firms, industries and value chains to networks and business ecosystems.
} 
demonstrate that technology not only helps to reduce related communication, information and search costs but also provides a superior mechanism to access talent and identify resources. Hence, technology provides the informational infrastructure for distributed innovation to occur.

Having said that, it is important to note that technology does not determine action within networks (Brynjolfsson, 1993). Rather, technologies afford (Gibson, 1977) "action possibilities" which are latent in their design without determining them (Orlikowski, 1992; Callon, 1987). Following this view, technology constitutes a space of possibilities; it is the task of organization design to transform these possibilities into actualities by structuring communication, coordination and control in distributed innovation systems. What then do we know about organization design of distributed innovation systems?

\section{The research question: design of distributed innovation systems}

Important works on motivation (Lerner and Tirole, 2002; von Krogh et al., 2012), leadership and governance mechanisms (O’Mahony and Ferraro, 2007; Fleming and Waguespack, 2007), forms of institutional work as logics and professional identities shift from firm-based to open models (Gawer and Phillips, 2013; Lifshitz-Assaf, 2015), boundary processes (O’Mahony and Ferraro, 2012; West and O’Mahony, 2008; Lakhani et al., 2013), relative openness and closure (West, 2003; Boudreau, 2012) and communities, socialization processes and power (Ducheneaut, 2005; Jarvenpaa et al., 2013; O’Mahony and Lakhani, 2011) have significantly deepened our understanding of the possibilities of managing distributed innovation strategically. These literatures share a concern with the managerial challenge of making use of distributed innovation and with the organizational challenge to develop absorptive capacity to appropriate external knowledge.

However, only relatively few studies have explicitly focused on the design mechanisms that structure communication, coordination and control in distributed innovation systems (see Baldwin, 2012; 
Gulati et al., 2012: Fjeldstad et al., 2012). Despite the shifting locus of innovation from firms towards networks, Gulati et al. (2012: 572) stated that

"our theories of organization design, with their strong intrafirm bias, continue to emphasize elements like formal authority [...], the design of incentives like salary, bonuses, benefits, and promotion opportunities, and the collocation of individuals performing highly interdependent tasks." (Gulati et al., 2012: 572)

The authors argued that the increase in collaboration with distributed external actors challenges this theoretization of design, with the consequence that "an emphasis on intrafirm design may be out of date, at the very least, incomplete.” (Gulati et al., 2012: 572). This diagnosis echoes Baldwin's (2012: 1) above quoted statement that individual organizations are "no longer adequate to serve as the primary unit of analysis". Indeed, as firms "shrink their core" and "expand their periphery" (Gulati and Kletter, 2005) the question of the design of collaborative processes becomes increasingly pertinent.

Whilst the literature on design of distributed innovation systems has articulated this challenge it has remained caught in a firm-centric perspective. For instance, Gulati et al. (2012: 582) introduced the notion of meta-organization which describes a cluster of legally autonomous firms or individuals that can be analyzed and designed as an organization. Their argument borrows much form the traditional hierarchical design thinking the paper aims to leave behind. Gulati et al.'s discussion of the two dimensions of meta-organization design - permeability of boundaries and stratification - serves as illustration. The question of boundaries is framed as decisions about granting membership to the meta-organization (2012: 576). The authors then discuss degrees of stratification within the metaorganization such as the control span as hierarchical design choice: "Like hierarchies in traditional organizations, tiering serves to specify spans of control within meta-organizations.” (2012: 578). 
Whilst traditional organization design supposed a manager-architect that engineered the relationships between individual employees, it is now the "focal firm" that plays the role of the system architect, shaping relationships amongst suppliers, partners and other network members. The corollary of Gulati et al.'s approach is that open communities are analytically distinguished by what they are lacking in comparison to hierarchically organized firms: boundaries towards the environment and internal stratification. Rather than investigating the specific processes that structure distributed innovation networks in which authorship of ideas, and by extension authority over the network, are distributed, the ideas put forward by Gulati et al. (2012) extend traditional firm-based design thinking.

Similarly, the notion of the actor-oriented design scheme proposed by Fjeldstad and his colleagues (2012) borrows much from the traditional organization design literature they criticize. For instance, discussing Accenture as case of an architecture of collaboration (2012: 740-741) the authors identify long-term development and training of staff, the IT-based internal knowledge management system, and general knowledge sharing between staff as critical design elements of the actor-oriented architectural scheme. The authors conclude that the characteristic feature of this and other examples is "that the locus of control and coordination mechanisms is the organizational actor." (2012: 744). Following this perspective, the shifting locus of innovation is accompanied with the affirmation of the firm as steady locus of design and control.

The critique of firm-centricity extends to much of the literature on design of distributed innovation systems, including studies on the design of platform innovation. For instance, in Gawer and Henderson's (2007) influential work on platform leadership, design is understood quite traditionally as the internal structuring of a firm (in their case, specifically job design at Intel; see Gawer, 2010: 292). Similarly, research on orchestration in network-centric innovation processes focused on leadership rather than design (Dhanaraj and Parkhe, 2006; Nambisan and Sawhney, 2011). For 
instance, Dhanaraj and Parkhe assumed that "the head cattle lead[s] the herd" thanks to superior managerial abilities (2006: 659). Such metaphorical framing re-captures if not the locus of innovation so at least the locus of control into the visible hand of the manager.

This points towards the problematic assumption in extant research that this paper addresses: research focused on design choices articulates the challenges of design in distributed innovation systems from a firm-centric perspective; yet a theory of organization design in distributed networks needs to provide a specific framework for understanding those mechanisms that structure decentralized innovation processes. It is the purpose of this paper to explicate such a framework, showing how design mediates the relationships between the "visible hand" of the manager and the "crowd" of unruly producer-consumers and other external contributors.

Note that such a framework does not make a-priori assumptions about the actors in or designers of distributed innovation networks: actors may include entrepreneurial individuals (e.g. Linus Torvalds), collectives (e.g. Wikipedia), crowds (e.g. TopCoder) or firms (e.g. Apple) that form elements of the distributed innovation system. The design principles that structure network relations merely describe how the pivotal tasks of communication, coordination and control between these heterarchical subsystems are accomplished. In this sense, individuals, collectives and firms are treated as elements (nodes) within the network that engage with each other through interfaces, participatory architectures and evaluative infrastructures. The authors of these interfaces, participatory architectures and evaluative infrastructures may include, but are not limited to, firms that seek to impose their designs on the "crowd". Alternatively, authorship might be shared between different actors and shift over time as design schemes evolve. Whilst these are important questions for future empirical research (see concluding section), this paper focuses on the principle design mechanisms that organize innovation networks. 
The next section explicates in detail the three design mechanisms that structure distributed innovation systems: interface design (mediating function); the design of architectures of participation (enabling function); and the design of evaluative infrastructures (valuation function). Akin to Baldwin and Clark's (2000) design rules for evolvable technical systems, these three dimensions of organization design in "the open" represent a complete set as they address the three fundamental concerns of organization design: interaction between elements; task differentiation and integration; and feedback (Simon, 1962).

\section{Design principles for organizing distributed innovation}

Design has been one of the key concerns for organization theorists (Simon, 1969; Perrow, 1967; March and Simon, 1958). As Dunbar and Starbuck (2006) suggested, traditionally, design has revolved around the notions of "alignment, congruence and fit" between the demands of an external environment and the internal parameters at the disposal of the manager, such as people, architecture, routines and culture (Roberts, 2004). Following this view, organization design is the internal response to the strategic choices of management, which in turn are determined by environmental constraints and opportunities (Chandler, 1962; Altman et al., 2015).

Distributed innovation problematizes organization design differently. It suggests shifting the unit of analysis from the individual firm to networks of actors and their relationships. As Baldwin (2012: 1) argued, "the key problem for organization design will be the management of distributed innovation" and the integration of diverse entities into coherent networks of value production. Because in distributed innovation systems the division of labor cuts across organizational boundaries and production feeds on multiple, distributed agents, the question of design cannot be understood as an internal organizational response to strategic choices. Rather, organization design co-evolves with distributed innovation. Take the example of Apple and its iPhone application ecology (see also Lakhani et al., 2012). Hundreds of thousands of applications are developed by external parties and 
sold via Apple's App Store. To a large degree, the experienced value and functional versatility of the iPhone results from the creativity of the distributed innovation systems surrounding it. Since the creation of innovative applications (including their marketing) occurs outside Apple's boundaries, the question of organization design shifts, too. Hence, whilst organization design refers to the structuring of communication, coordination and control in both closed and open systems, the mechanisms with which communication, coordination and control are accomplished in networks are different.

Analytically this raises three distinct questions: First, how is the interaction between actors in distributed innovation systems structured? Second, how are production processes designed so that distributed actors with different motivations, skills and commitment levels can contribute meaningfully? And third, how can actors evaluate the results of distributed innovation and assess its qualities?

\section{Principle \#1: Interface design}

Hierarchies are communication structures that determine chains of command (down) and lines of reporting (up). They are oblivious toward horizontal communication. In contrast, when interacting with distributed innovation systems, the task of design is to facilitate horizontal communication between network actors, including firms, on the one hand, and external producers in distributed innovation systems, on the other.

Organizational design addresses the problem through the design of interfaces. ${ }^{4}$ An interface is defined as a medium that organizes the exchange between two or more heterarchically distributed elements (Galloway, 2012). Interfaces can take many forms: online examples include forums, portals

\footnotetext{
${ }^{4}$ Note that communication in hierarchies is also enabled through interfaces (reports, performance reviews, personnel assessments etc. can be read as interfaces). The point of the analysis offered in this paper is to explore the specificity of those interfaces that act as filters structuring access to and the exchange of information horizontally between two or more elements within distributed innovation systems. I would like to thank one of the reviewers for bringing this point to my attention.
} 
and websites that structure the flow of information and communication; offline, events such as conferences or innovation camps provide interfaces between firms and communities; boundary objects facilitate interaction between different epistemic communities (Nicolini et al., 2012); and, more institutionally, boundary organizations such as the EU-sponsored Living Labs, or consultancies such as Hyve, provide structure to the interaction between distributed innovators, including crowds and and firms (Almirall and Wareham, 2008; O’Mahony and Bechky, 2008). These examples point towards the main characteristic of an interface. It acts as a filter that structures access to and the exchange of information between two or more elements. ${ }^{5}$

Analytically, interfaces have several important dimensions. First, as Simon (1969) posited, interfaces are "meeting points" mediating between internal and external environments. They structure the interaction between different parties by organizing the exchange of information. Consider, for example, the interface on email software that allows for three different types of recipients: those addressed directly, those copied in and those blind copied. In a subtle yet powerful way, the interface structures choice between alternatives. In this sense, interfaces exercise power; they are "architectural control points" (Woodward, 2008) that enable and constrain interaction simultaneously. "The common interface", explained Langlois and Garzarelli, "enables, but also governs and disciplines, the communication among subsystems" (2005: 9). Interfaces represent often technologically mediated affordances that encourage certain actions (e.g. press like button to show support) and make others less likely (e.g. expressing dissensus on Facebook).

Second, and closely related, interfaces organize boundaries to enable communication between heterarchical subsystems. While extant research has elaborated on the shifting nature and

${ }^{5}$ A technical interface is commonly analyzed as standard, which structures exchange within a network (e.g. MPG as a technical standard that allows electronic file sharing). Whilst technical standards play an important role, this paper focuses on communication interfaces (see Baldwin and Clark, 2000). 
permeability of boundaries (O’Mahoney and Ferraro, 2012; Lakhani et al., 2013; Lifshitz-Assaf, 2015), a focus on interfaces invites the researcher to zoom into the actual design of boundaries and the passages through which information flows. On a micro-level, interfaces may be analyzed as formatting devices that govern exchange across boundaries. The notion of formatting captures the role of technology and its affordances in structuring communication through interfaces (Orlikowski, 1992).

Third, and in contradistinction to traditional organizational design, interfaces do not promote integration. In distributed innovation systems, the integration of external producers would be detrimental, as Chatterji and Fabrizio argued: "If firms attempt to bring users into the firm to capture their unique knowledge assets, they risk losing the attributes that make user input valuable in the first place" (2012: 984). There are three reasons for the diminishing return of integrating external actors: socially, integration means that they grow distant from their network, which has been their source of innovation (Powell et al., 1996); cognitively, integrated actors adapt to dominant frames (March, 1991); and motivationally, contractual obligations and economic incentives might lead to crowding out effects (Fehr and Falk, 2002).

The specificity of interfaces resides in their ability to create communication between heterogeneous elements while maintaining their differences. Galloway and Thacker (2007) used the notion of interoperability to describe how interfaces mediate between dissimilar data forms. The aim of mediating interfaces is to create communication across multiplicities without reducing their differences; they are mechanisms for translation, not assimilation.

In sum, the concept of interface design expands related concepts of boundary spanning (Aldrich and Herker, 1977), brokers (Burt, 1992) and the debate on absorptive capacities (Cohen and Levinthal, 1990; Zahra and George, 2002) in significant ways. An interface represents systematically designed 
points of interaction between an element (for instance, a firm) and its surrounding network that are:

(1) meeting points between internal and external elements which (2) translate heterogeneous contributions into organizationally readable formats and (3) structure the work and decisions of those producing in distributed innovation networks more or less clandestinely. ${ }^{6}$

A good example of the versatility of interface design is the social networking site Facebook, which uses an existing technology (the internet), existing hardware (computers, smartphones, etc.) and freely available programming languages (codes) and combines them to create supposedly unique value for its users (see Baldwin, 2012: 9). In effect, Facebook's value-add basically amounts to an adept layering of interfaces on top of each other - for what else is Facebook if not a clever nesting of interfaces onto a database generated by user activities?

\section{Principle \#2: Design of architectures of participation}

Hierarchically organized production is characterized as a grammar to reduce complexity and ambiguity (Weick, 1979). Equally, distributed innovation systems rely on a grammar to coordinate tasks and integrate outputs. However, in contrast to hierarchical design, the grammar of distributed innovation has to allow for distributed actors with varying degrees of motivation, skill and commitment levels to contribute to something that emerges without the planning of a managerial mastermind. Hence, rather than organizing internal differentiation and integration, architectures of participation provide a design mechanism for the integration of external production (Baldwin and Clark, 2006; building on Simon, 1962; see also O’Reilly, 2004).

\footnotetext{
${ }^{6}$ As one reviewer pointed out, there is a noteworthy parallel to Hayek's idea that prices organize communication horizontally between distributed network actors. Prices may fulfil this function in a production-focused (commodity-based) economy. However, in economic situations characterized by uncertainty and ambiguity about the value of a new idea, product or service the price mechanism fails. Therefore, horizontal communication between distributed network actors is accomplished through a plethora of new interfaces and evaluative infrastructures that organize supply and demand.
} 
Architectures of participation structure the collaboration in distributed innovation systems by designing open production processes. Following Baldwin and Clark (2006), these architectures of participation refer to three design characteristics that organize collaboration within distributed innovation systems. First, modularity refers to the idea that products can be deconstructed into modular units and developed independently of each other. This is important as different people with different skills may work at different times with different speeds on different aspects of one and the same project. The modularity principle echoes Simon's (1962) idea of a decomposable system in which modular units interact with each other through interfaces. The benefit of such a decomposable system is higher stability in the face of environmental uncertainty achieved through a loose coupling of elements. Second, the principle of granularity states that modules have to be small in size so that a given project attracts people with different levels of motivation and commitment (Benkler, 2002). For instance, on Wikipedia, rating the usefulness of an entry with a click or researching and writing a new entry from scratch illustrate the breadth of possible levels of contribution. Third, low integration costs are pivotal as the task of relating modular and granular elements to each other would otherwise create costs that outrun the gains achieved through distributed innovation. Integration can occur in various forms (Benkler, 2002: 441). For instance, a second order peer-production mechanism can be used for the integration of the modular units, as is the case in review-based quality control systems. Forms of normative control can act as mechanisms of integration and quality control, such as in the case of Wikipedia (see Duguid, 2006 on the limits of self-organization). Other forms of integration include technology which can perform the integrative function by specifying conditions of integration, or, a temporary return of managerial hierarchy. For instance, Linux developer community uses this mechanism for important decisions about system evolution.

Importantly, architectures of participation do not reduce complexity (like traditional organization design does), but increase complexity in a controlled way. Lego provides a good example of how a simple system that adheres to modularity, granularity and low integration costs can provide the 
grammar for open-ended creative expression. Indeed, Lego blocks can be understood as a language that allows, through grammar and vocabulary, the creation of complex artifacts and experiences (Antorini, 2007). Hence, distributed innovation is not limited by the overall complexity of a task, but by the modular, granular and integrative characteristics of a given project (Benkler, 2002).

There is a growing number of examples that illustrate the playful application of architectures of participation in practice. One of the early examples was the "mole game" developed by the Finnish National Library. ${ }^{7}$ The computer game invited players to build bridges for moles by typing words that appear on a screen. The words, instead of being random, were ones the automatic scanning program of the Finnish National Library found illegible. Hence, players solved an otherwise costly undertaking for the library. Scientists have developed similar gamification strategies to solve laborious tasks. For instance, in the game Eyewire, amateur gamers map the connections of the nervous system of the eye, while Foldit is an online puzzle in which players fold protein structures.

These examples point towards the importance of an intelligent architecture of participation to enable collaboration in distributed networks: in all three cases, complex challenges are broken down into tasks that are modular (the problem can be decomposed into small sub-problems), granular (you can play once or many times, every input matters) and where integration costs remain low (technology collects and processes gaming results). Such a modular, granular and integrative Lego-esque architecture provides a language for people to contribute to projects in the "open". Architectures of participation may also impact on the expressiveness and creativity of actors in the distributed innovation system, for every language is also always a system of rules (grammar) that structures what can be said, and what cannot.

\footnotetext{
${ }^{7}$ http://dailycrowdsource.com/20-resources/projects/579-a-game-of-moles-crowdsourcing-thearchives-of-the-finnish-national-library
} 
Principle \#3: Design of evaluative infrastructures

In distributed innovation systems, the most valuable resources for production - know-how and human ingenuity - are located outside firm boundaries. Interfaces and effective architectures of participation result in a wealth of contributions. In fact, in many distributed innovation networks there are too many ideas, products and experiences on offer. Think of websites such as kickstarter.com, where to date more than 80,000 projects ranging from fashion to film and music have been funded by over eight million investors, pledging more than $\$$ US1.6 billion. The problem then becomes: how to evaluate innovations and ensure quality control?

Evaluative infrastructures can be defined as methodologies and technologies of valuation that are distributed across innovation networks. They are methodologies because they presuppose certain epistemological assumptions about what is valuable as well as calculative practices through which things can be evaluated (Miller, 2001). They are technologies because they could not exist without a plethora of material evaluation devices that measure, quantify, index, compare, fix and calculate values (Karpik, 2010). Examples of evaluative infrastructures include, e.g. rankings, ratings, reviews, tagging, bestseller lists and awards (see Espeland and Sauder, 2007; Karpik, 2010; Orlikowski and Scott, 2014). They can be produced either by users (TripAdvisor or Facebook's like button), experts (awards) or automatically through algorithms (Amazon's reference function or Google Search). In all instances, the "click" plays a pivotal role; it represents a new epistemological category in which thinking and action, decision making and execution coincide. And, because every click leaves a trace, it provides much of the raw material for evaluative infrastructures.

Evaluative infrastructures evolve in parallel to distributed innovation systems. They fulfill several important functions. First, they represent accounting regimes that make things visible (Miller, 2001). For instance, trust has been identified as an important characteristic in knowledge intensive production processes (Adler, 2001). How do distributed innovators who have never met each other 
develop trust in each other? Evaluative infrastructures represent technologies that make trust visible. For example, the online accommodation provider Airbnb is an interface for people who would like to rent out their apartment temporarily and for tourists who would prefer staying in a more personal, cheaper home rather than an anonymous, expensive hotel. The service begs the question of trust: how can you offer your apartment to someone you have never met? Airbnb's success is based on its solution to this problem, which involves a rating system that creates a reputation for each user. After each stay, both parties evaluate each other, which creates a profile that will impact on one's future ability to either rent or lease a flat. The Airbnb co-founder, Nathan Blecharczyk, described reputation as the social currency that makes the exchange work. ${ }^{8}$

More generally, reputation gains are important motivators for contributors to distributed innovation (Lerner and Tirole, 2002). Through valuation practices, reputation is made visible, which, in turn, motivates members to contribute. Hence, evaluative infrastructures generate a reputation economy by providing the scaffolding for people to build their careers in "the open". An illustrative example of this mechanism is TopCoder.com, which hosts competitions between its more than 750,000 talented programmers and software designers, and connects them with firms that are in need of software solutions (see Boudreau et al., 2011). Top coders' achievements are displayed on the website, the quality of the coders' reputations indicated by badges awarded according to a "progress meter". Through such visualizations, evaluations allow the build-up of cultural and symbolic capital.

Evaluative infrastructures do not merely make values visible; they are also constitutive of new values. Having a certain number of followers in an online network such as Twitter is a new form of social value that is inextricably linked to the technology that allows for its visualization. Reference tools, such as Amazon's “If you like books by [author's name], you might like ...”, create new cartographies of products, bestowing forms of symbolic and cultural value upon them by relating

${ }^{8}$ Interview in Die Zeit, no. 34, August 16, 2012, p. 28. 
them. The networking site LinkedIn asks its users to tag ("endorse") members in their network, making qualities visible that constitute new profiles. Hence evaluative infrastructures engender new forms of accounting for multiple values. They are mechanisms to quantify qualities and coin new currencies, such as trust quantified as grade on a scale (AirBnB) or an overall sellers rating (eBay). In so doing they do not simply measure, but actively co-constitute new values.

In effect evaluative infrastructures play an important role in organizing sense-making and decisionmaking. As argued, distributed innovation invites a wealth of proposals, prototypes and products that are launched continuously. The question is how to navigate these productions that no-one asked for and how to find those that are valuable and reliable. In a hierarchical system selection is based on apriori defined criteria; in distributed innovation networks, selection is based on a-posteriori evaluations (Benkler, 2006). Rankings, ratings and other evaluation devices represent regimes of valuation that categorize and hierarchize products emerging from distributed innovation systems. Virtually anything (downloads, citations, references, etc.) can serve as raw material for valuations. And, since everything leaves a trace, virtually every activity can be translated into an input for a higher-level evaluation (e.g. papers feed citation analyses, which feed the h-index, etc.). These cascades of valuations create (at least temporarily stable) taxonomies that allow for users to make sense and decision. As Karpik (2010) put it, valuation devices are cognitive prosthesis that help consumers through an increasingly complex world. Put simply, evaluative infrastructures emerge at the point where the scare resource is the cognitive capacity to weigh alternatives. In fact, Apple's App Store ranks Apps that are hip, TripAdvisor suggests where to eat and sleep, and Google proposes the most relevant answer to a particular inquiry; in each of these three instances, evaluative infrastructures categorize and hierarchize otherwise overwhelming amount of new products, idea and experiences and through doing so support sense- and decision-making.

\section{Discussion}




\section{Reconfiguring organization design in distributed innovation systems}

As scholars from a variety of fields have suggested, given modern communication technology and a wealth of new organizational forms, the locus of innovation shifts from firms to open networks. This paper suggests a framework for the study of how organization design accomplishes communication, coordination and control in such networks. Interfaces, architectures of participation, and evaluative infrastructures represent the design mechanisms that organize network interaction and transaction.

This framework advances organization design's traditional analytical vocabulary. To date, organization design scholars have not responded sufficiently to the challenges and opportunities of this shift towards distributed innovation (Dunbar and Starbuck, 2006). Foundational work from the middle of the last century is still providing the vocabularies for current debates (March and Simon, 1958; Burns and Stalker, 1961; Chandler, 1962; Woodward, 1965; Lawrence and Lorsch, 1967). For instance, Chandler proposed understanding structure as, "the design of the organization through which the enterprise is administered" (1962: 14), including internal hierarchical structuring of organization, division of labor (differentiation and integration), managerial control and performance measurement systems (see also Altman et al., 2015). The key concern is to create "fit" between exogenous forces and what is treated as internal variables, such as people, architectures, routines and culture (Roberts, 2004). But when economic activity is organized outside the boundaries of hierarchically organized firms, managers may have little or no jurisdiction over those variables and the performance of those who were neither hired by them nor can be fired by them.

The contribution that this paper makes is to show how organization design can be conceptualized as a novel form of structuring communication, coordination and control in distributed innovation systems. The key tenet of this paper is that distributed innovation systems are characterized by three specific design parameters: In the first place, interfaces structure interaction within distributed innovation systems; in the second place, architectures of participation provide a language through 
which network innovators with varying degrees of commitment, motivation and skills can articulate their contributions; and finally evaluative infrastructures encompass rankings, ratings and a myriad of other evaluation devices through which products are being compared, commensurated and categorized.

Most importantly, the primary function of organization design in distributed innovation systems is not to actually organize production or to innovate, but to provide the conditions in which distributed innovators can do so. To return to the example of Ford: At the beginning of the twentieth century, Ford's assembly line provided an internalized infrastructure that organized production. The knowledge economy requires a different kind of infrastructure, one that invites distributed actors to contribute and co-create. The assembly line is, so to speak, folded from the inside of the firm out onto the innovation network. This infrastructure does not enforce internal hierarchy but consists of multiple nested interfaces mediating between heterarchically organized, heterogeneous subsystems; it does not differentiate and integrate tasks internally, but offers a language for external actors to become co-authors of novel ideas, products and technologies; it does not strive for assimilation but represents a mechanism for translation; and, finally, it does not directly control those who produce but provides evaluative infrastructures that order and hierarchize what is produced in "the open".

\section{Implications for theory}

Design as mechanism to organize "the open" has some further implications for theories of search and the resource-based view.

First, theorizing the "visible hand" and the "crowd" transforms the organizational search problem (March, 1991). Researchers have repeatedly argued that outstanding organizational performance results form strategic leaders' "superior ability to manage the mental processes necessary to pursue cognitively distant opportunities" (Gavetti, 2012: 267). Yet, a well-established body of literature has 
evolved over the decades that shows management's structural problems with search. For instance, Salancik and Pfeffer (1974) argued that power dynamics determine resource allocation, making organizations paradoxically fit to respond to threats but, in the long run, unfit to cope with new challenges. March described the "competency trap" (Levitt and March, 1988) which results from successful past experience. Experience, he argued, "is likely to generate confidence more reliably than it generates competence and to stop experimentation too soon" (March, 2010: 114). Because core competencies easily become “core rigidities" (Leonard-Barton, 1992), today’s success may breed tomorrow's failure.

The proposed framework shifts the question of search as an experiential and cognitive task (Gavetti and Levinthal, 2000) towards search as a distributed process facilitated by organizational design. Distributed innovation systems are comprised of a large number of actors with different needs, competencies and objectives. The actors are distributed heterachically and, each conditioned by their own bounded rationalities, perform searches for new ideas according to their own evaluation criteria. In other words, search is performed amongst a variety of distributed actors who have their own definition of what counts (Stark, 2009). But what structures such a seemingly chaotic search process? The proposed theory of design suggests three organizing principles for such searches. Organization design in distributed innovation systems explicates: 1) how contending search filters can interact via interfaces; 2) how individual actors can build onto each others' contributions; and 3) how different valuations come about.

In regards to search, the last point deserves special emphasis. Evaluative infrastructures are epistemic machines that scan open networks for different values, monitoring, comparing and visualizing them. From Facebook's like button to TopCoder's reputation hierarchies and Amazon's cross-referencing categorization system, these and other mechanisms have to be understood as evaluation tools that monitor how orders of worth emerge. Hence, evaluative infrastructures represent "heterogeneous 
systems of accounting for worth" (Stark 2009: 25), which are in and of themselves valuable, as Stark elaborated, "Where the organizational environment is turbulent and there is uncertainty what might constitute a resource under changed conditions, contending frameworks of value can themselves be a valuable organizational resource" (2009: 6).

Second, the arguments put forward in this paper have implications for the resource-based view of the firm. The resource-based view suggests that sustainable competitive advantage is rooted in an organization's specific resources, competencies and capabilities (Wernerfelt, 1984; Prahalad and Hamel, 1990; Barney, 1991; Teece et al. 1997). Prahalad and Hamel (1990) suggested the metaphor of a tree, where products and services resemble the leaves exposed to the wind and weather, but where the true "roots of competitiveness" are to be found in the core competencies, hidden deep down in the soil, the roots storing away a firm's main resource (knowledge). However, the image of roots as representing an organization's most valuable assets is misleading; rather, knowledge is distributed across networks and located outside organizational boundaries. Hence, it is not ownership or other forms of direct control over resources that bestows a competitive advantage on firms, but rather access to resources (Rifkin, 2000). For strategy, this raises the question: How can access be organized? This paper has identified three mechanisms that can facilitate access to resources outside firm boundaries. Interface design organizes access and exchange between heterachically organized subsystems; architectures of participation provide the language (alphabet and grammar) to co-author innovative narratives and ideas; and evaluative infrastructures represent ordering mechanisms that classify, categorize and hierarchize co-created products and services. Moreover, evaluative infrastructures make visible resources such as talent (TopCoder), reputation (reviews on Airbnb) or trust (eBay) which are in turn the crucial inputs for further strategic thought and action (see for the example of eBay Baron, 2001; Saeedi et al., 2013). In short, the proposed analytics of organization design in distributed innovation systems contributes to the resource-based view by explicating how external resources can be identified, coordinated, and to some degree, governed. 
These suggestions have implications for the debate between strategy and structure more generally. Under conditions of a distributed resource base, it can be hypothesized that strategy does not determine structure, but that an organization's interface design, participatory architecture and evaluative infrastructures determine its strategic options. By extension, organizational design is not a question of fit, but a generative force that creates new possibilities. To return to Prahalad and Hamel's metaphor, the competencies of a firm are not its roots; competencies reside in its ability to design interfaces between externally situated know-how; to provide architectures for meaningful conversation and collaboration; and to develop evaluative infrastructures to make contributions visible and valuable.

\section{Implications for further empirical research}

This paper's conceptual vocabulary invites to broaden the empirical research agenda of scholars studying the strategic organization of distributed innovation systems.

Following Baldwin's (2012) call this paper provided a conceptualization of organization design that does not take the individual firm but the network as unit of analysis. It suggests studying interfaces, participatory architectures and evaluative infrastructures as pivotal design mechanisms that structure communication, coordination of tasks and control in distributed innovation systems. Future empirical research might focus on concrete enactments of these design mechanisms in practice: How do interfaces format the flow, direction and density of information in distributed innovation networks? How do these interfaces as architectural control points facilitate translations across boundaries, and what is lost in translation? How are modularity, granularity and low integration costs accomplished in networks? In how far do participatory architectures (akin to languages) preconfigure network actors' experiences of the present and imagination of possible futures? How do evaluative infrastructures commensurate, categorize and hierarchize the contributions of network 
actors, establishing new orders of worth? And how do these evaluations inform sense-making and decision-making of network actors, consumers and other stakeholders? Such empirical research into organization design of networks needs to be complemented with a focus on the specific affordances of technology: how does technology, including devices, applications, software, algorithms, etc. structure the space of possible actions of network actors? Such empirical inquiry into the organization design in networks will also produce insights into the relationships between actual organization designs and networks' innovation capacity and overall agility.

Last but not least the suggested conceptualization of organization design in distributed innovation systems invites further empirical analysis of the question of authorship of designs. Avoiding firmcentricity, future research might analyse authorship of interfaces, participatory architectures and evaluative infrastructures as distributed phenomenon. Authors may include, but are not limited to, firms that seek to impose their designs on the "crowd" as well as actors, such as entrepreneurs, collectives and others that play significant roles in the emergence and ongoing evolution of designs. Bringing in a temporal, dynamic perspective, over time authors' roles might range from active codesigners to users that appropriate dominant designs through their (performative) routines, bending and sometimes breaking design rules.

\section{Concluding reflections}

Theorizing organization design between the "visible hand" and the "crowd" invites a concluding speculation. As Drucker (2002) argued, management is perhaps the most important socio-technical invention of the twentieth century. Management's legitimacy is based on its efficiency claim, and thus managers, at least theoretically, are held accountable for how the organization performs.

Distributed innovation challenges this theoretization of the manager. In the context of distributed innovation, the manager does not have formal authority over the production process. The 
legitimizing claim of efficiency gains through managerial coordination cannot be upheld either. Rather, unruly producer-consumers and other external agents whom the manager can neither hire nor fire are valuable yet also uncontrollable organizational resources. In this context, the managerial challenge shifts from being focused on the efficient allocation of internal resources to a concern with organizing "the open", i.e. designing structures and systems for coordinating work outside company walls (Boudreau and Lakhani, 2013).

How, then, can we rethink the role of the manager? Perhaps managing could be re-imagined as practice of diplomacy, with diplomacy defined as the "attempt to govern the ungovernable - the anarchical society - through discursive and cultural practices” (Der Derian, 1987:4). Diplomacy is a potentially fruitful metaphor for describing management in "the open" because, historically, the power of diplomacy evolved in inverse relation to the demise of the power of the sovereign. Foreign cultures had to be decoded diplomatically because they could not any longer be firmly oppressed or safely ignored. In other words, diplomacy marks the sovereign's tacit acknowledgement that the world is polycentric. The disaggregation of authority into multiple "spheres of authority" (Rosenau, 2007 ; 1997) might not only characterize international but also organizational relations. In open networks characterized by shifting alliances, dispersed leadership, distributed agency and multiple authorship, the manager's tasks might start resembling that of a diplomat, as both are concerned with creating the conditions for collective action to occur.

Following from that, and emphasizing the Galbraith quote cited at the beginning of this paper, it is not ideological debates for or against capitalism that matter; rather, it is the imperatives of technology and organization that shape society. New practices of value creation in distributed innovation networks and new design mechanisms to organize "the open" may represent part and parcel of such imperatives. Whether or not distributed innovation represents a new form of organizing economic activity or merely an attempt to hollow out bureaucracies; whether it will lead to groupthink on an 
unprecedented scale or valuable new ideas; whether it will debunk the expert and install a regime of populism instead, these questions will depend at least partly on how distributed innovation comes to be integrated into existing circuits of production and power. For better or worse, organization design as a mechanism to structure the interaction between the "visible hand" and the "crowd" will play a crucial role in these attempts to organize (and perhaps to disorganize) "the open". 


\section{References}

- Adler P (2001) Market, hierarchy, and trust: The knowledge economy and the future of capitalism. Organization Science 12(2): 215-234.

- Afuah A and Tucci CL (2012) Crowdsourcing as a solution to distant search. Academy of Management Review 37: 355-375.

- Afuah A and Tucci CL (2013) Value capture and crowdsourcing. Academy of Management Review 38(3): 457-460.

- Aldrich H and Herker D (1977) Boundary spanning roles and organization structure. Academy of Management Review April: 217-230.

- Almirall E and Wareham J (2008) Living labs and open innovation: Roles and applicability. The Electronic Journal for Virtual Organizations and Networks 10(3): 21-46.

- Altmand EJ, Nagle F and Tushman ML (2015) Innovating without Information Constraints: Organizations, Communities, and Innovation when Information Costs Approach Zero. In: Shalley MH and Zhou J (eds) Oxford Handbook of Creativity, Innovation, and Entrepreneurship: Multilevel Linkages. Oxford UK: Oxford University Press, pp. 353-379.

- Antorini YM (2007) Brand Community Innovation - An Intrinsic Case Study of the Adult Fans of LEGO Community. PhD Copenhagen Business School.

- Baldwin CY (2012) Organization design for distributed innovation. Harvard Business School Working Paper May 4 2012: 12-100.

- Baldwin C and Clark K (2000) Design Rules: the Power of Modularity. Cambridge: MIT Press.

- Baldwin C and Clark K (2006) The architecture of participation: Does code architecture mitigate free riding in the open source development model? Management Science 52(7): 11161127.

- Baldwin C and von Hippel E (2011) Modeling a paradigm shift: From producer innovation to user and open collaborative innovation. Organization Science 22(6): 1399-1417.

- Barney J (1991) Firm resources and sustained competitive advantage. Journal of management 17(1): 99-120.

- Baron DP (2001) Private Ordering on the Internet: The eBay Community of Traders. Graduate School of Business Stanford University Research Paper Series No. 1709.

- Benkler Y (2002) Coase's Penguin, or, Linux and the nature of the firm. The Yale Law Journal 112(3): 369-446.

- Benkler Y (2006) The wealth of networks: How social production transforms markets and freedom. Yale University Press.

- Bloodgood J (2013) Crowdsourcing: Useful for problem solving, but what about value capture? Academy of Management Review 38(3): 455-457.

- Bogers M and West J (2012) Managing distributed innovation: Strategic utilization of open and user innovation. Creativity and innovation management 21(1): 61-75.

- Boudreau KJ (2012) Let a thousand flowers bloom? An early look at large numbers of software app developers and patterns of innovation. Organization Science 23(5): 1409-1427.

- Boudreau KJ, Lacetera N and Lakhani KR (2011) Incentives and problem uncertainty in innovation contests: An empirical analysis. Management Science 57(5): 843-863.

- Boudreau KJ and Lakhani KR (2009) How to manage outside innovation. MIT Sloan Management Review Summer: 69-76.

- Boudreau KJ and Lakhani KR (2013) Using the crowd as innovation partner. Harvard Business Review April: 61-69.

- Brynjolfsson E (1993) The productivity paradox of information technology. Communications of the ACM 36(12): 66-77.

- Burns T and Stalker GM (1961) The Management of Innovation. London: Tavistock. 
- Burt R (1992) Brokerage and Closure: An Introduction to Social Capital. Oxford, NY: Oxford University Press.

- Callon M (1987) Society in the making: the study of technology as a tool for sociological analysis. In: Bijker W, Hughes TP, Pinch T et al. (eds) The social construction of technological systems: New directions in the sociology and history of technology. MIT Press, pp. 88-103.

- Chandler A (1962) Strategy and Structure: Chapters in the History of the American Enterprise. Boston, MA: MIT Press.

- Chatterji $A$ and Fabrizio K (2011) How do product users influence corporate invention. Organization Science 23: 951-970.

- Chesbrough HW (2003) Open Innovation: The New Imperative for Creating and Profiting from Technology. Boston: Harvard Business School Press.

- Chesbrough HW (2006) Open innovation: A new paradigm to understanding industrial innovation. In: Chesbrough HW, Vanhaverbeke W and West J (eds) Open Innovation: Researching a New Paradigm. Oxford: Oxford University Press, pp. 1-12.

- Cohen WM and Levinthal DA (1990) Absorptive capacity: A new perspective on learning and innovation. Administrative Science Quarterly 35(1): 128-152.

- Der Derian J (1987) On Diplomacy: A Genealogy of Western Estrangement. Oxford and New York: Basil Blackwell.

- Dhanaraj C and Parkhe A (2006) Orchestrating innovation networks. Academy of Management Review 31(3): 659-669.

- Drucker P (2002) Managing in the Next Society. New York: Truman Talley Books/St. Martin's Press.

- Ducheneaut N (2005) Socialization in an open source software community: A sociotechnical analysis. Computer Supported Cooperative Work 14: 323-368.

- Duguid P (2006) Limits of self-organization: peer production and 'laws of quality'. First Monday 11(10). Available at: http:// firstmonday.org/article/view/1405/1323\#author

- Dunbar RL and Starbuck WH (2006) Learning to design organizations and learning from designing them. Organization Science 17(2): 171-178.

- Espeland W and Sauder M (2007) Rankings and reactivity: How public measures recreate social worlds. American Journal of Sociology 113(1): 1-40.

- Fehr E and Falk A (2002) Psychological foundations of incentives. European Economic Review 46: 687-724.

- Fjeldstad OD, Snow CC, Miles RE et al. (2012) The architecture of collaboration. Strategic Management Journal 33: 734-750.

- Fleming L and Waguespack DM (2007) Brokerage, boundary spanning, and leadership in open innovation communities. Organization Science 18(2): 165-180.

- Fosfuri A, Giarratana MS and Luzzi A (2008) The penguin has entered the building: The commercialization of open source software products. Organization Science 19(2): 292-305.

- Galbraith JK (1967) The New Industrial State. New York: New American Library.

- Galloway A (2012) The Interface Effect. Cambridge and Malden: Polity Press.

- Galloway A and Thacker E (2007) The Exploit: A Theory of Networks. Minneapolis and London: University of Minnesota Press.

- Gavetti G and Levinthal D (2000) Looking forward and looking backward: Cognitive and experiential search. Administrative science quarterly 45(1): 113-137.

- Gavetti G (2012) Towards a behavioral theory of strategy. Organization Science 23(1): 267-285.

- Gawer A (2010) The organization of technological platforms. Research in the Sociology of Organizations 29: 287-296.

- Gawer A and Cusumano M (2002) Platform Leadership: How Intel, Microsoft and Cisco drive industry innovation. Boston, MA: Harvard Business School Press. 
- Gawer A and Cusumano MA (2008) How companies become platform leaders. MIT/Sloan Management Review 49.

- Gawer A and Henderson R (2007) Platform owner entry and innovation in complementary markets: Evidence from Intel. Journal of Economics \& Management Strategy 16(1): 1-34.

- Gawer A and Phillips N (2013) Institutional work as logics shift: The case of Intel's transformation to platform leader. Organization Studies 34(8): 1035-1071.

- Gibson JJ (1977) The Theory of Affordances. In: Shaw R and Bransford J (eds) Perceiving, Acting, and Knowing: Toward an Ecological Psychology. Hillsdale, NJ: Lawrence Erlbaum, pp. 6782.

- Gulati R and Kletter D (2005) Shrinking core - expanding periphery: the relational architecture of high performing organizations. California Management Review 47(1): 77-104.

- Gulati R, Puranamn P and Tushman M (2012) Meta-organization design: rethinking design in interorganizational and community contexts. Strategic Management Journal 33: 571-586.

- Huston L and Sakkab N (2006) Connect and develop: Inside Procter \& Gamble's new model for innovation. Harvard Business Review 84(3): 58-66.

- Jarvenpaa SL, Lim R and Tuunainen VK (2013) Ambidextrous Socialization: Exercising Control in Social Media Environment. In: System Sciences (HICSS), 2013 46th Hawaii International Conference. IEEE, pp. 660-669.

- Karpik L (2010) Valuing the Unique: The Economics of Singularities. Princeton and Oxford: Princeton University Press.

- Lakhani KR, Lifshitz-Assaf H and Tushman M (2012) Open innovation and organizational boundaries: the impact of task decomposition and knowledge distribution on the locus of innovation. Harvard Business School Technology \& Operations Mgt. Unit Working Paper 12-57.

- Lakhani KR, Lifshitz-Assaf H and Tushman M (2013) Open Innovation and Organizational Boundaries: Task Decomposition, Knowledge Distribution and the Locus of Innovation. In: Grandori A (eds) Handbook of Economic Organization: Integrating Economic and Organization Theory. Northampton, MA: Edward Elgar Publishing, pp. 355-382.

- Lakhani KR and Panetta JA (2007) The principles of distributed innovation. Innovations 2(3): 97-112.

- Langlois $\mathrm{R}$ (2003) The vanishing hand: The changing dynamics of industrial capitalism. Industrial and Corporate Change 12(2): 351-385.

- Langlois R and Garzarelli G (2005) Of hackers and hairdressers: Modularity and the organizational economics of open-source collaboration. Unpublished paper.

- Lawrence PR, Lorsch JW and Garrison JS (1967) Organization and environment: Managing differentiation and integration. Boston, MA: Division of Research, Graduate School of Business Administration, Harvard University.

- Leonard-Barton D (1992) Core capabilities and core rigidities: A paradox in managing new product development. Strategic Management Journal 13: 111-125.

- Lerner J and Triole J (2002) Some simple economics of open source. Journal of Industrial Economics 52(June): 197-234.

- Levitt B and March J (1988) Organizational learning. Annual Review of Sociology 14: 319-340.

- Lichtenthaler U (2011) Open innovation: past research, current debates, and future directions. Academy of Management Perspectives 25(1): 75-93.

- Lifshitz-Assaf H (2015) From Problem Solvers to Solution Seekers: The Permeation of Knowledge Boundaries at NASA. SSRN. Available at SSRN: http://ssrn.com/abstract=2431717 or http://dx.doi.org/10.2139/ssrn.2431717

- March J (1991) Exploration and exploitation in organizational learning. Organization Science 2(1): 71-87.

- March J (2010) The Ambiguities of Experience. Ithaca and London: Cornell University Press. 
- March JG and Simon HA (1958) Organizations. New York: Wiley.

- Miller P (2001) Governing by numbers: Why calculative practices matter. Social Research.

- Nambisan S and Sawhney M (2011) Orchestration processes in network-centric innovation: Evidence from the field. The Academy of Management Perspectives 25(3): 40-57.

- Nicolini D, Mengis J and Swan J (2012) Understanding the role of objects in crossdisciplinary collaboration. Organization Science 23(3): 612-629.

- Normann R and Ramirez R (1993) From value chain to value constellation: Designing interactive strategy. Harvard business review 71(4): 65-77.

- O’Mahony S and Bechky BA (2008) Boundary organizations: Enabling collaboration among unexpected allies. Administrative Science Quarterly 53(3): 422-459.

- O'Mahony S and Ferraro F (2007) The emergence of governance in an open source community. Academy of Management Journal 50(5): 1079-1106.

- O'Mahony S and Ferraro F (2012) Managing the boundary of an 'open project'. In: Padgett J and Powell W (eds) Market Emergence and Transformation. Princeton, NJ: Princeton University Press.

- O’Mahony S and Lakhani KR (2011) Organizations in the Shadow of Communities. In: Marquis C, Lounsbury M and Greenwood R (eds) Communities and Organizations. Research in the Sociology of Organizations. Emerald Group Publishing, pp. 3-36.

- O'Reilly T (2004) The Architecture of Participation. Available at: http://oreilly.com/pub/a/oreilly/tim/articles/architecture of participation.html (accessed 24 October 2013)

- Orlikowski W and Scott S (2014) What happens when evaluation goes online? Exploring apparatuses of valuation in the travel sector. Organization Science 25(3): 868-891.

- Orlikowski WJ (1992). The duality of technology: Rethinking the concept of technology in organizations. Organization Science 3(3): 398-427.

- $\quad$ Perrow C (1967) A framework for the comparative analysis of organizations. American Sociological Review 32(2): 194-208.

- $\quad$ Pisano GP and Verganti R (2008) Which kind of collaboration is right for you. Harvard Business Review 86(12): 78-86.

- Powell WW (1990)Neither market nor hierarchy: Network forms of organization. In: Staw BM and Cummings LL (eds) Research in Organizational Behavior. JAI, pp. 295-336.

- Powell WW, Koput KW and Smith-Doerr L (1996) Interorganizational Collaboration and the Locus of Innovation: Networks of Learning in Biotechnology. Administrative Science Quarterly 41: 116-145.

- Prahalad CK and Hamel G (1990) The Core Competence of the Corporation. Harvard Business Review 68(3): 79-91.

- Prahalad CK and Ramaswamy V (2004) The Future of Competition: Co-creating Unique V alue with Customers. Boston, MA: Harvard Business School Press.

- Rifkin J (2000) The Age of Access. New York: Jeremy P. Tarcher/Putnam.

- Roberts J (2004) The Modern Firm: Organizational Design for Performance and Growth. Oxford: Oxford University Press.

- Rosenau JN (1997) Along the Domestic-Foreign Frontier: Exploring Governance in a Turbulent World. Cambridge: Cambridge University Press.

- Rosenau JN (2007) Governing the ungovernable: The challenge of a global disaggregation of authority. Regulation and Governance 1: 88-97.

- Saeedi M, Shen Z and Sundaresan N (2013) The V alue of Feedback: An Analysis of Reputation System. Working Paper The Obio State University.

- Salancik GR and Pfeffer J (1974) The bases and use of power in organizational decision making: The case of a university. Administrative Science Quarterly 19(4): 453-473. 
- Simon H (1969) The Sciences of the Artificial. Cambridge: The MIT Press.

- Simon HA (1962) The architecture of complexity. Proceedings of the American philosophical society 106(6): 467-482.

- Stark D (2009) The Sense of Dissonance: Accounts of Worth in Economic Life. Princeton, NJ: Princeton University Press.

- Teece DJ, Pisano G and Shuen A (1997) Dynamic capabilities and strategic management. Strategic Management Journal 18(7): 509-533.

- Vargo S and Lusch R (2004) Evolving to a new dominant logic for marketing. Journal of Marketing 68: 1-17.

- von Hippel E (1976) The dominant role of users in the scientific instrument innovation process. Research Policy 5: 212-239.

- von Hippel E (1986) Lead users: a source of novel product concepts. Management Science 32(7): 791-806.

- von Hippel E (1988) The Sources of Innovation. New York and Oxford: Oxford University Press.

- von Hippel E (2005) Democratizing Innovation. Cambridge: The MIT Press.

- von Krogh G, Haefliger S, Spaeth S et al. (2012) Carrots and rainbows: Motivation and social practice in open source software development. MIS Quarterly 36(2): 649-676.

- Weber S (2004) The Success of Open Source. Cambridge and London: Harvard University Press.

- Weick K (1979) The Social Psychology of Organizing. Reading, MA: Addison-Wesley.

- Wernerfelt B (1984) A resource based view of the firm. Strategic Management Journal 5(2): 171180.

- West J and O'Mahony S (2008) The role of participation architecture in growing sponsored open source communities. Industry and Innovation 15(2): 145-168.

- West J (2003) How open is open enough? Melding proprietary and open source platform strategies. Research Policy 32(7): 1217-1241.

- Williamson EO (1985) The economic institutions of capitalism: firms, markets and relational contracting. The Free Press.

- Williamson OE (1991) Introduction. In: Williamson OE and Winter S (eds) The Nature of the Firm. Origins, Evolution, and Development. Oxford University Press, pp. 3-17.

- Woodward J (1965) Industrial organization: Theory and practice. London: Oxford University Press.

- Woodward J (2008) Architectural control points. In: Vaishnavi V and Baskerville R (eds) Proceedings of the Third International Conference on Design Science Research in Information Systems and Technology May 7- 9, 2008. Atlanta, GA: Georgia State University.

- Yates J (1989) Control Through Communication: The Rise of System in American Management. Baltimore, MD: Johns Hopkins University Press.

- Zahra SA and George G (2002) Absorptive Capacity: A Review, Reconceptualization, and Extension. Academy of Management Review 27(2): 185-203.

- Zammuto RF, Griffith TL, Majchrzak A et al. (2007) Information technology and the changing fabric of organization. Organization Science 18(5): 749-762. 


\section{Biographical note}

Martin Kornberger is an undisciplined mind: he received his $\mathrm{PhD}$ in Philosophy from the University of Vienna in 2002 and has held positions in strategy, organization theory, marketing and design. After a decade in Sydney he currently works at Copenhagen Business School. He is also a visiting professor at The University of Edinburgh Business School and a research fellow at the Vienna University of Economics and Business. With an eclectic bookshelf behind him, his eyes are firmly focused on organizing practices that constrain, enable and sometimes subvert the organizational imagination of practitioners and scholars. He can be contacted at mko.ioa@,cbs.dk 